\title{
Cervical Cancer pT3a TNM Finding v7
}

National Cancer Institute

\section{Source}

National Cancer Institute. Cervical Cancer pT3a TNM Finding v7. NCI Thesaurus. Code C89541.

Cervical cancer involves lower third of vagina, without extension to pelvic wall. (from AJCC 7th Ed.) 